\title{
PEMENUHAN HAK ANAK BERKEBUTUHAN KHUSUS DI SEKOLAH INKLUSI
}

\author{
Triyanto \\ Desty Ratna Permatasari \\ Prodi PPKn FKIP Universitas Negeri Sebelas Maret \\ Jl. Ir. Sutami 36 A Surakarta 57126 \\ E-mail: try_uns@yahoo.com
}

\begin{abstract}
Special children's rights fulfillment in inclusive school SDIT Al Irsyad Al Islamiyyah 02 Purwokerto. The aim of this study is to describe the fulfilling of special needs children's' rights in inclusive school SDIT Al Irsyad Al Islamiyyah 02 Purwokerto. The qualitative descriptive research was applied and the data collection of data was using questionnaires, interview, and observation. The subjects of the study are classroom teachers and teacher assistant. The results of the study showed that SDIT Al Irsyad Al Islamiyyah 02 Purwokerto has been able to apply the inclusive school concept. Although not all of special children's needs are fulfilled, they have been generally fulfilled.
\end{abstract}

Keywords: special children's rights fulfillment, inclusive school

\begin{abstract}
Abstrak: Pemenuhan Hak Anak Berkebutuhan Khusus di Sekolah Inklusi SDIT Al Irsyad Al Islamiyyah 02 Purwokerto. Penelitian ini bertujuan untuk menggambarkan pemenuhan hakhak anak berkebutuhan khusus (ABK) di sekolah inklusif SDIT Al Irsyad Al Islamiyyah 02 Purwokerto. Jenis penelitian deskriptif kualitatif. Teknik pengumpulan data menggunakan metode angket, wawancara dan observasi. Subyek penelitian adalah guru kelas dan guru pendamping. Hasil penelitian menunjukkan bahwa SDIT Al Irsyad Al Islamiyyah 02 Purwokerto telah mampu menerapkan konsep sekolah inklusi dengan cukup baik. Meski masih belum semua hak ABK terpenuhi, namun secara umum hak-hak ABK telah dapat terpenuhi.
\end{abstract}

Kata kunci: pemenuhan hak-hak ABK, sekolah inklusif.

Setiap anak memiliki ciri khas serta kelebihan yang berbeda-beda satu sama lain. Anak dengan kebutuhan khusus merupakan salah satu contoh perbedaan ciri khas dari seorang anak. Perbedaan tersebut harus diapresiasi dengan baik oleh individu yang berada di lingkungan anak. Penerimaan yang baik dari lingkungan merupakan salah satu hak yang harus diterimanya. Sayangnya, tidak semua pihak-pihak tersebut menyadari bahwa penerimaan dari mereka akan berpengaruh terhadap kondisi psikis anak. Komisi Perlindungan Anak Indonesia (KPAI) pada tahun 2014 kembali mendapat laporan tentang kasus dugaan kekerasan terhadap Anak Berkebutuhan Khusus (ABK) berusia 14 tahun hingga menimbulkan luka fisik, yang telah dilakukan oleh pihak sekolah.

Laporan yang diterima KPAI (2014) terkait kekerasan fisik pada ABK juga terjadi di sekolah yang berbasis boarding school. Terkait kasus tersebut KPAI memberikan rekomendasi kepada Kemendikbud agar melakukan evaluasi terhadap penyelenggaraan boarding school untuk anak berkebutuhan khusus. Tindakan preventif dari pemerintah untuk meredakan maraknya kasus kekerasan atau diskriminasi pada anak dianggap sangat perlu dilakukan. Kegiatan evaluasi serta monitoring penyelenggaraan sekolah untuk ABK harus dilakukan semaksimal mungkin. Dalam hal 
ini, pemerintah juga mempunyai andil yang besar terkait posisinya sebagai pembuat undang-undang bagi perlindungan warga negara.

Kasus kekerasan dan diskriminasi pada ABK masih dianggap hal wajar dalam realita kehidupan di masyarakat. Hal ini seperti diungkapkan oleh Susanto selaku Komisioner bidang pendidikan KPAI bahwa "diskriminasi kepada anak yang berkebutuhan khusus dan anak-anak minoritas dianggap hal wajar. Kekerasan dipandang sebagai hal yang lazim dilakukan dalam rangka mendidik anak". Anggapan ini tentu sangat merugikan ABK selaku "korban" yang mempunyai hak-hak layaknya anak pada umumnya. Anak dengan kebutuhan khusus juga harus dikembangkan potensi dalam dirinya agar kelak mereka mampu membaur dalam lingkup masyarakat yang lebih luas setelah dewasa.

Tindak kekerasan serta diskriminasi yang diterima oleh ABK di Indonesia sepertinya belum menjadi masalah bagi masyarakat luas. Hal tersebut menunjukkan tingkat kepedulian masyarakat dengan kehidupan ABK yang masih rendah. Seorang ABK di Kulonprogo ditolak sebuah sekolah saat mendaftar tanpa alasan yang jelas (Tribun Jogja, 2014). Hal ini menunjukkan belum semua sekolah memiliki visi yang jelas dalam mengakomodir pendidikan bagi siswa berkebutuhan khusus. Pihak sekolah sebagai lembaga formal penyelenggara pendidikan seharusnya tidak mempermasalah-kan masalah keterbatasan fisik siswa. Hal ini dikarenakan setiap anak mempunyai hak yang sama untuk memperoleh pendidikan.

Dampak lingkungan sosial bagi perkembangan mental atau psikologi anak harus benar-benar disadari oleh semua pihak terkait. Sekolah yang notabene sebagai salah satu lingkungan yang bernuansa pendidikan harus menerapkan prinsipprinsip kesamaan hak bagi semua siswanya tak terkecuali bagi siswa ABK. Nuansa pendidikan yang diciptakan di sekolah harus berlandaskan dengan nilai-nilai yang tidak bertentangan dengan konsep mendidik itu sendiri. Bahwa mendidik seorang anak sama halnya seperti membentuk karakternya. Saat seorang anak dididik dengan kekerasan maka dalam diri siswa akan tertanam karakter sebagai seorang yang pemarah dan mudah melakukan kekerasan.

\section{Anak Berkebutuhan Khusus (ABK)}

Menurut Mulyono(2006:26) anak berkebutuhan khusus diartikan sebagai anak yang mempunyai kecacatan atau yang menyandang ketunaan, dan juga anak lantib dan berbakat. Seiring perkembangannya, makna ketunaan dapat diartikan sebagai berkelainan atau luar biasa. Konsep ketunaan berbeda dengan konsep berkelainan. Konsep ketunaan cenderung mengarah kepada orang yang mempunyai kecacatan sedangkan konsep berkelainan atau luar biasa mempunyai makna yang lebih luas yaitu mencakup anak yang menyandang ketunaan maupun yang memiliki keunggulan.

Di sisi lain, menurut Heward (2003) anak berkebutuhan khusus adalah anak yang mempunyai karakteristik berbeda dengan anak pada umumnya tetapi tidak berarti perbedaan tersebut selalu mengarah kepada ketidakmampuan secara mental, emosi atau fisik. Menurut Mangunsong (2009) anak berkebutuhan khusus atau anak luar biasa adalah anak yang mempunyai perbedaan dalam hal; ciriciri mental, kemampuan-kemampuan sensorik, fisik dan neuromaskular, perilaku sosial dan emosional, kemampuan berkomunikasi, maupun campuran dari dua atau lebih hal-hal di atas dari rata-rata anak normal; ia memerlukan perubahan yang mengarah pada perbaikan tugas-tugas sekolah, metode belajar atau pelayanan lainnya, yang bertujuan untuk mengembangkan potensi atau kemampuannya secara maksimal. Berdasarkan dari beberapa pendapat ahli di atas, maka dapat disimpulkan bahwa anak berkebutuhan khusus adalah anak yang mempunyai ciri khas berbeda dibandingkan anak pada umumnya, dimana ciri khas tersebut terkait dengan fisik, emosi, maupun mental yang berada di bawah maupun di atas rata-rata anak pada umumnya.

Menurut Permendiknas No. 70 tahun 2009 pasal 3 ayat 1: peserta didik yang berhak mengikuti pendidikan secara inklusif pada satuan pendidikan tertentu sesuai dengan kebutuhan dan kemampuannya adalah peserta didik yang memiliki memiliki kelainan fisik, emosional, mental dan sosial atau memiliki potensi kecerdasan dan/atau bakat istimewa. Sedangkan pada pasal 3 ayat 2 disebutkan bahwa "tunanetra, tunarungu, tunawicara, tunagrahita, tunadaksa, tunalaras, berkesulitan belajar, lamban belajar, autis, memiliki gangguan motorik, menjadi korban penyalahgunaan narkoba, obat terlarang, dan zat adiktif lainnya, memiliki kelainan lainnya, dan tunaganda merupakan jenis peserta didik yang memiliki kelainan sebagaimana dimaksud dalam ayat 1 . 
Tunanetra adalah seseorang yang memiliki keterbatasan yang berupa hambatan dalam penglihatan. Tunanetra Dapat diklasifikasikan kedalam dua golongan yaitu: buta total (blind) dan low vision. Keadaan lemah penglihatan atau akurasi penglihatan kurang dari 6/60 setelah dikoreksi atau tidak lagi melihat disebut tunanetra (Hallahan \& Kaufman, 2006). Karena tunanetra memiliki keterbataan dalam indra penglihatan maka proses pembelajaran ditekankan pada alat indra yang lain yaitu indra peraba dan indra pendengaran. Oleh karena itu prinsip yang harus diperhatikan oleh guru dalam memberikan pengajaran kepada seseorang yang memiliki keterbatasan penglihatan adalah penggunaan media yang harus bersifat aktual dan bersuara, contohnya adalah penggunaan tulisan braille, gambar timbul, benda model dan benda nyata. sedangkan media yang bersuara adalah tape recorder dan alat lain.

Tunarungu adalah kekurangan atau kehilangan kemampuan mendengar baik sebagian atau seluruhnya yang dialamai oleh individu, penyebabnya yaitu karena tidak fungsinya sebagian atau seluruh alat pendengaran, sehingga individu tersebut tidak dapat menggunakan alat pendengarannya dalam kehidupan sehari-hari (Winarsih, 2007). Terhambatnya perkembangan bahasa anak merupakan salah satu akibat yang ditimbulkan dari gangguan pada individu yang tunarungu. Di sisi lain, menurut Somad dan Hernawati (1995) tunarungu adalah kekurangan atau kehilangan kemampuan mendengar baik sebagian atau seluruhnya yang dialami oleh individu, penyebabnya yaitu karena tidak fungsinya sebagian atau seluruh alat pendengaran, sehingga ia tidak dapat menggunakan alat pendengarannya dalam kehidupan sehari-hari yang berpengaruh terhadap kehidupannya secara keseluruhan.

Tunawicara merupakan gangguan atau keterbatasan verbal pada seseorang sehingga mengalami kesulitan dalam berkomunikasi melalui suara. Tunawicara sering dikaitkan dengan tunarungu. Sebagian tunawicara adalah mereka yang menderita tunarungu sejak bayi atau lahir, hal tersebut disebabkan seseorang yang memiliki keterbatasan pendengaran tidak dapat menangkap pembicaraan orang lain, sehingga tidak mampu mengembangkan kemampuan bicaranya meskipun tidak mengalami gangguan pada alat suaranya (Sadjaah, 2005). Jadi dapat ditarik kesimpulan bahwa mempunyai gangguan pendengaran sejak balita maupun sejak lahir akan menjadi anak yang menderita gangguan berbicara.

Tunagrahita menurut Peraturan Pemerintah Republik Indonesia Nomor 72 Tahun 1991 tentang Pendidikan Luar Biasa adalah keterbelakangan mental, termasuk disini yang keterbelakangan mental ringan dan keterbelakangan mental sedang. Ada beberapa klasifikasi tuna grahita menurut American Association on Mental Deficiency (AAMD) (Amin, 1995). Pertama, Tunagrahita Ringan (Mampu Didik). Tingkat kecerdasannya IQ mereka berkisar 50-70, anak yang menderita tugrahita ringan mempunyai kemampuan untuk berkembang dalam bidang pelajaran akademik, penyesuaian sosial dan kemampuan untuk bekerja, mampu melakukan penyesuaian dengan lingkungan yang lebih luas, dapat mandiri dalam masyarakat, mampu melakukan pekerjaan semi trampil dan pekerjaan sederhana. Kedua, Tunagrahita Sedang (Mampu Latih). Tingkat kecerdasan IQ berkisar 30-50, dapat belajar keterampilan sekolah untuk tujuan fungsional, mampu mengurus dirinya sendiri (self-help), mampu melakukan penyesuaian sosial dalam lingkungan terdekat, mampu mengerjakan pekerjaan rutin tetapi harus diawasi. Ketiga, Tunagrahita Berat dan Sangat Berat (Mampu Rawat). Tingkat kecerdasan IQ mereka kurang dari 30, hampir tidak dapat dilatih untuk mengurus diri sendiri. Ada yang masih mampu dilatih mengurus diri sendiri, hanya mampu berkomunikasi secara sederhana dan dapat beradaptasi dengan lingkungan tetapi sangat terbatas.

Tunadaksa adalah individu yang mengalami kerusakan atau gangguan atau hambatan pada tulang, otot dan sendi dalam melakukan fungsinya secara normal. Penyebabnya dapat dikarenakan oleh penyakit, kecelakaan atau dapat juga disebabkan oleh pembawaan sejak lahir (Somantri, 2006). Menurut Peraturan Pemerintah Republik Indonesia Nomor 72 Tahun 1991 tentang Pendidikan Luar Biasa tunadaksa adalah cacat tubuh. Menurut Peraturan Pemerintah Republik Indonesia Nomor 72 Tahun 1991 tentang pendidikan luar biasa, tunalaras adalah individu yang memiliki gangguan atau hambatan atau kelainan tingkah laku sehingga mereka kurang dapat beradaptasi dengan baik terhadap lingkungan keluarga, sekolah, dan masyarakat.

Berkaitan dengan anak berkesulitan belajar, istilah yang digunakan cukup bervariasi. Keragaman 
istilah ini disebabkan oleh sudut pandang ahli yang berbeda-beda. Kelompok ahli bidang medis menyebutnya dengan istilah brain injured, dan minimal brain dysfunction, kelompok ahli psikolinguistik menggunakan istilah language disorders, dan selanjutnya dalam bidang pendidikan ada yang menyebutnya dengan istilah educationally handicaped. Istilah umum yang sering digunakan oleh para ahli pendidikan adalah learning disabilities.

Public Law (Hallahan \& Kauffman, 2006) menjelaskan tentang "Specific Learning Disabilities" sebagai individu yang mempunyai gangguan pada satu proses psikologis dasar atau yang lebih terlihat di dalam penggunaan bahasa secara lisan dan tulisan dengan wujud seperti ketidaksempurnaan mendengar, memikirkan, membicarakan, membaca, menulis, mengucapkan atau melakukan penghitungan matematis. Jadi, dapat disimpulkan bahwa ABB merupakan jenis gangguan pada anak dalam menerima atau menjalani proses pembelajaran, ketidakmampuan siswa tersebut disebabkan oleh adanya ketidaksempurnaan kemampuan untuk melakukan hal-hal dasar dalam melakukan pembelajaran.

Berkaitan dengan anak berkebutuhan khusus lainnya adalah autisme. Kata autisme berasal dari bahasa Yunani yang terdiri dari dua kata yaitu "aut" yang berarti diri sendiri dan "ism" yang secara tidak langsung menyatakan orientasi atau arah atau keadaan (state). Kartono (2003) berpendapat bahwa autism adalah gejala untuk menutup diri sendiri secara total, dan tidak mau bersosialisasi lagi dengan dunia luar sehingga mereka terlalu asyik fikiran dan imajinasi sendiri. Yatim (2002) mengemukakan bahwa autisme adalah keadaan seseorang yang menunjukan gejala kelainan tingkah laku dan perkembangan yang mana terjadi penyimpangan perkembangan sosial, kemampuan berbahasa dan kepedulian terhadap sekitar, sehingga anak autisme seperti hidup dalam dunainya sendiri serta terjadi kelainan emosi, intelektual dan kemauan (gangguan pervasive).

Dari keterangan di atas, maka dapat disimpulkan bahwa autisme adalah gejala menutup diri sendiri secara total, dan tidak mau berhubungan lagi dengan dunia luar, merupakan gangguan perkembangan yang komplek, mempengaruhi perilaku, dengan akibat kekurangan kemampuan komunikasi, hubungan sosial dan emosional dengan orang lain dan tidak tergantung dari ras, suku, strata-ekonomi, strata sosial, tingkat pendidikan, geografis tempat tinggal, maupun jenis makanan.

Kelainan ganda menurut Peraturan Pemerintah Republik Indonesia Nomor 72 Tahun 1991 tentang Pendidikan Luar Biasa, seseorang yang memiliki gabungan kelainan fisik dan mental disebut tunaganda. Kolaborasi dari dua atau lebih kelainan fisik yang dimiliki oleh individu tentu akan sangat berakibat dalam proses kehidupan pribadi maupun kehiduan sosialnya.

\section{Hak-Hak Anak Berkebutuhan Khusus}

Anak-anak berkebutuhan khusus mempunyai kesetaraan dengan warga negara lainnya termasuk hak pendidikan. Kesetaraan hak mereka dengan warga negara lain ditegaskan dalamPasal 31 UndangUndang Dasar 1945 yang menyatakan bahwa "Tiaptiap warga negara berhak mendapat pengajaran". Undang-Undang No. 20 Tahun 2003 tentang Sistem Pendidikan Nasional juga mengatur secara khusus perlindungan terhadap anak berkebutuhan khusus. Pasal 8 ayat 1 UU No. 20/2003 menyatakan bahwa "Warga negara yang memiliki kelainan fisik atau mental berhak memperoleh pendidikan luar biasa" Pasal 15 UU No. 20/2003 menyatakan bahwa Jenis pendidikan bagi Anak berkebutuan khusus adalah Pendidikan Khusus. Pasal 32 ayat 1 UU No. 20/2003 memberikan batasan bahwa "Pendidikan khusus merupakan pendidikan bagi peserta didik yang memiliki tingkat kesulitan dalam mengikuti proses pembelajaran karena kelainan fisik, emosional, mental, sosial, dan/atau memiliki potensi kecerdasan dan bakat istimewa".

Menurut Pasal 52 Undang-Undang Republik Indonesia No. 23 tahun 2002 tentang Perlindungan Anak menyatakan bahwa "Anak yang memiliki keunggulan diberikan kesempatan dan aksesbilitas untuk memperoleh Pendidikan Khusus." Artinya bahwa anak dengan kecerdasan dan bakat istimewa (keunggulan) juga termasuk anak yang memerlukan penanganan khusus sehingga berhak diikutsertakan dalam Pendidikan Khusus.

Menurut Pasal 5 Undang-Undang Republik Indonesia No. 4 Tahun 1997 tentang Penyandang Cacat menyatakan bahwa "Setiap penyandang cacat mempunyai hak dan kesempatan yang sama dalam segala aspek kehidupan dan penghidupan". Aspek kehidupan dan penghidupan meliputi aspek pendidikan yang diperoleh penyandang cacat 
melalui pendidikan khusus pada semua satuan, jenis dan jenjang pendidikan.

Menurut Pasal 3 Permendiknas No. 70 tahun 2009 tentang Pendidikan Inklusi menyatakan bahwa "setiap peserta didik yang memiliki kelainan fisik, emosional, mental dan sosial atau memiliki potensi kecerdasan dan/atau bakat istimewa berhak mengikuti pendidikan secara inklusif pada satuan pendidikan tertentu sesuai dengan kebutuhan dan kemampuannya.

Peraturan Pemerintah Republik Indonesia Nomor 72 Tahun 1991 tentang Pendidikan Luar Biasa menyatakan bahwa peserta didik berkebutuhan khusus mempunyai hak: (1) memperoleh perlakuan sesuai dengan bakat, minat, kemampuan, dan kelainannya; (2) memperoleh pendidikan agama sesuai dengan agama yang dianutnya; (3) mengikuti program pendidikan yang bersangkutan atas dasar pendidikan berkelanjutan, baik untuk mengembangkan kemampuan diri maupun untuk memperoleh pengakuan tingkat pendidikan tertentu yang telah dibakukan; (4) memperoleh bantuan fasilitas belajar, beasiswa, atau bantuan lain sesuai dengan kelainan yang disandang dan persyaratan yang berlaku; (5) pindah ke sekolah yang sejajar atau melanjutkan ke tingkat yang lebih tinggi sesuai dengan kelainan yang disandang dan persyaratan penerimaan siswa pada sekolah yang hendak dimasuki; (6) memperoleh penilaian hasil belajar; (7) menyelesaikan program pendidikan lebih awal dari waktu yang ditentukan; dan (8) memperoleh pelayanan khusus sesuai dengan jenis kelainan yang disandang.

Bentuk dari pendidikan bagi ABK adalah Pendidikan Inklusi. Menurut Pasal 1 Permendiknas No. 70 tahun 2009, pendidikan Inklusi adalah sistem penyelenggaraaan pendidikan yang memberikan kesempatan kepada semua peserta didik yang memiliki kelainan dan memiliki potensi kecerdasan dan/atau bakat istimewa untuk mengikuti pendidikan atau pembelajaran dalam satu lingkungan pendidikan secara bersama-sama dengan peserta didik pada umumnya. Menurut Pasal 2 Permendiknas No. 70 tahun 2009 pasal 2, tujuan dari pendidikan Inklusif adalah: (a) memberikan kesempatan yang seluas-luasnya kepada semua peserta didik yang memiliki kelainan fisik, emosional, mental dan sosial atau memiliki potensi kecerdasan dan/atau bakat istimewa untuk memperoleh pendidikan yang bermutu sesuai dengan kebutuhan dan kemampuannya. (b) mewujudkan penyelenggaraan pendidikan yang menghargai keanekaragaman, dan tidak diskriminatif bagi semua peserta didik.

Saat ini pemerintah sedang mengembangkan pendidikan inklusi di berbagai sekolah. Salah satu sekolah yang menerapkan konsep pendidikan inklusi adalah SDIT Al Irsyad Al Islamiyyah 02 Purwokerto. Berdasarkan latar belakang tersebut, maka penelitian ini akan menggambarkan sejauh mana pemenuhan hak ABK di sekolah Inklusif di SDIT Al Irsyad Al Islamiyyah 02 Purwokerto.

\section{METODE}

Penelitian ini menggunakan jenis deskriptif kualitatif. Penelitian deskriptif kualitatif adalah penelitian yang dirancang untuk menggambarkan keadaaan sosial apa adanya tanpa melihat hubungan yang ada. Penelitian ini dirancang untuk menjelaskan pemenuhan hak-hak ABK di SD inklusif SDIT Al Irsyad Al Islamiyyah 02 Purwokerto. Penelitian deskriptif kualitatif yang digunakan adalah studi kasus.

Teknik pengumpulan data yang digunakan dalam penelitian ini adalah berupa angket, wawancara, dan observasi. Jenis angket yang digunakan yaitu angket langsung tertutup berisi 11 pertanyaan dengan diberi alternatif jawaban "ya" atau "tidak". Angket yang digunakan diberikan kepada seluruh guru damping dan guru kelas berjumlah 7 orang yang menangani langsung siswa ABK di kelas. Adapun wawancara dilakukan kepada perwakilan dari guru pendamping yaitu kepada ibu Lili Riskiningtyas S.Pd. Observasi dilakukan pada bulan April 2016.

Teknik analisis data menggunakan statistik deskriptif dan analisis data kualitatif. Statistik deskriptif digunakan untuk menyajikan hasil pengumpulan data secara secara deskriptif. Salah satu jenis statistik deskriptif yang digunakan adalah distribusi frekuensi. Teknik analisis data kualitatif digunakan untuk mendeskripsikan data secara lebih dalam.

\section{HASIL DAN PEMBAHASAN}

Terdapat delapan hak-hak yang harus diperoleh ABK dari pihak sekolah sebagaimana tertuang dalam PP No. 72 Tahun 1991 tentang Pendidikan Luar Biasa. Dari delapan hak ABK tersebut, penelitian ini menggunakan tujuh indikator hak 
untuk mengukur pemenuhan hak-hak ABK di Sekolah Inklusi SDIT Al Irsyad Al Islamiyyah 02 Purwokerto. Hal ini disesuaikan dengan judul dan fokus penelitian dimana hak nomor 5 tentang "pindah sekolah" tidak ditemukan di lokasi penelitian. Hasil angket, wawancara dan observasi terhadap ketujuh indikator hak siswa ABK dapat di deskripsikan sebagai berikut.

\section{Hak Memperoleh Perlakuan sesuai Bakat, Minat, Kemampuan, dan Kelainannya}

Komponen pertama yang ditelah berkaitan dengan pemenuhan hak anak berkebutuhan khusus adalah hak memperoleh perlakuan sesuai bakat, minat, kemampuan, dan kelainannya. Hasil analisis data, secara garis besar, disajikan pada Tabel 1 .

Tabel 1: Hasil Analisis Kurikulum Sesuai Bakat, Minat, dan Kemampuan

\begin{tabular}{|c|c|c|}
\hline \multirow{2}{*}{ Pertanyaan } & \multicolumn{2}{|c|}{ Jawaban } \\
\hline & Ya & Tidak \\
\hline $\begin{array}{l}\text { Kurikulum sekolah mempunyai } \\
\text { tujuan untuk mengembangkan } \\
\text { potensi siswa berkebutuhan } \\
\text { khusus. }\end{array}$ & 7 orang & - \\
\hline
\end{tabular}

Berdasarkan Tabel 1, dapat digarisbawahi bahwa hasil angket menunjukkan hak siswa untuk memperoleh perlakuan yang sesuai dengan bakat, minat, kemampuan dan kelainannya telah terpenuhi secara optimal oleh pihak sekolah. Dapat dilihat dari jumlah responden yang menjawab "Ya" ada 7 orang artinya semua responden guru menjawab "Ya". Menurut hasil wawancara dengan Ibu Lili Riskiningtyas selaku guru damping ABK, perlakuan yang didapatkan oleh siswa $A B K$ sesuai dengan kondisinya, contohnya yaitu saat siswa ABK dengan jenis tunalaras sedang mengerjakan soal di kelas namun dia tidak mampu menyesuaikan dengan keadaan kelas yang tenang, dia akan terus bermain sendiri sampai berpindah posisi dengan berjalan ke tempat duduk temannya maka guru akan menegurnya dan jika siswa tersebut masih tidak mau mengikuti aturan di kelas, maka guru dan siswa tersebut membuat kesepakatan untuk mengerjakan soal sesuai dengan kemauan siswa, misal di luar kelas atau di perpustakaan. Tetapi dengan persyaratan bahwa siswa harus menyelesaikan soal yang sedang dikerjakan dengan batas waktu yang telah ditentukan.
Hasil observasi yang dilakukan juga mempunyai fakta yang sejalan dengan hasil angket dan wawancara, bahwa siswa yang memiliki keterbatasan atau ABK mendapat perlakuan yang sesuai dengan jenis keterbatasannya. Dalam kaitan ini kompetensi khusus bidang layanan ABK menurut Sudayat (2014) mencakup pemahaman perilaku, pembelajaran pendidikan khusus, penanganan suatu gejala, dan perawatan terhadap peserta didik. Mereka akan lebih dimaklumi oleh pihak guru jika dalam menerima pembelajaran atau menyelesaikan soal-soal pelajaran cenderung lambat. Pemenuhan hak ini telah sesuai dengan Pasal 50 UU No. 23 Tahun 2002 tentang Perlindungan Anak yang menyatakan bahwa pendidikan diarahkan pada pengembangan sikap dan kemampuan kepribadian anak, bakat, kemampuan mental dan fisik sampai mencapai potensi mereka yang optimal.

\section{Hak Memperoleh Pendidikan Agama sesuai dengan Agama yang Dianutnya}

Komponen kedua yang ditelaah berkaitan dengan pemenuhan hak anak berkebutuhan khusus adalah hak memperoleh pendidikan agama sesuai dengan agama yang dianutnya. Hasil analisis data, secara garis besar disajikan pada Tabel 2.

\section{Tabel 2: Hasil Analisis Hak Memperoleh Pendidikan Agama}

\begin{tabular}{lcc}
\hline \multicolumn{1}{c}{ Pertanyaan } & \multicolumn{2}{c}{ Jawaban } \\
\cline { 2 - 3 } & \multicolumn{1}{c}{ Ya } & Tidak \\
\hline Sekolah menyelenggarakan & orang & - \\
kegiatan keagamaan bagi siswa & & \\
ABK untuk mengembangkan & & \\
kecerdasan spiritual & \\
\hline
\end{tabular}

Berdasarkan informasi dari Tabel 2, dapat diketahui bahwa hak siswa ABK untuk memperoleh pendidikan agama sesuai dengan agama yang dianutnya telah terpenuhi dengan maksimal oleh pihak sekolah. Hal tersebut dapat dilihat dari jumlah guru yang menjawab "Ya" pada butir pernyataan nomor 2 yaitu berjumlah 7 orang yang artinya semua respoonden guru menjawab "Ya". Informasi yang diperoleh dari hasil wawancara dengan pihak guru, bahwa kegiatan keagamaan yang rutin dilaksanakan di SDIT Al Irsyad Al Islamiyyah 02 Purwokerto meliputi kegiatan tartil Al Quran yang dilakukan setelah kegiatan belajar mengajar selesai maupun 
solat berjamaah yang dilakukan bersama antara siswa dengan guru. SDIT Al Irsyad Al Islamiyyah 02 Purwokerto adalah sekolah dasar Islam terpadu dan seluruh siswanya beragama Islam sehingga kegiatan keagamaan yang dilaksanakan di sekolah adalah kegiatan agama Islam.

Pemenuhan pendidikan agama bagi siswa ABK telah sesuai dengan Pasal 12 UU No. 20 Tahun 2003 tentang Sistem Pendidikan Nasional yang menyatakan bahwa siswa berhak memperoleh pendidikan dari guru agama yang seagama dengan siswa. Pemenuhan pendidikan agama ini merupakan hak sangat penting ditengah masih terjadinya beberapa diskriminasi pendidikan agama di beberapa daerah di Indonesia dimana siswa tidak menerima pendidikan agama sesuai dengan agama mereka (Triyanto, 2015).

\section{Hak Mengikuti Program Pendidikan}

Komponen ketiga yang ditelaah adalah pemenuhan hak mengikuti program pendidikan. Berkaitan dengan hak ABK untuk mengikuti pendidikan berkelanjutan, baik untuk mengembangkan kemampuan diri maupun untuk memperoleh pengakuan tingkat pendidikan tertentu yang telah dibakukan. Hasil wawancara kepada guru menyatakan bahwa tidak semua jenis ABK dapat masuk di SDIT Al Irsyad Al Islamiyyah 02 Purwokerto, jika jenis ABK masih dapat ditangani oleh pihak sekolah maka siswa ABK tersebut dapat masuk ke SDIT Al Irsyad Al Islamiyyah 02 Purwokerto. Pihak sekolah menyesuaikan dengan kapasitas kemampuan guru damping dan guru kelas yang berada di sekolah, jadi tidak semua jenis ABK dapat masuk di SDIT Al Irsyad Al Islamiyyah 02 Purwokerto.

Hasil observasi dan wawancara menginformasikan bahwa hak untuk mengikuti program pendidikan yang bersangkutan atas dasar pendidikan berkelanjutan, baik untuk mengembangkan kemampuan diri maupun untuk memperoleh pengakuan tingkat pendidikan tertentu yang telah dibakukan belum dapat dipenuhi secara keseluruhan. Dalam hal penerimaan peserta didik baru belum terdapat kriteria yang jelas. Keterlibatan siswa ABK dalam kegiatan sekolah belum dilakukan secara maksimal. Masih ada beberapa guru yang memilih tidak melibatkan ABK dalam kegiatan sekolah dengan alasan untuk memudahkan kegiatan yang akan dilaksanakan. Siswa ABK juga belum semua mendapat prioritas yang sama dalam kegiatan kelas. Hal ini menunjukkan bahwa tingkat pengakuan terhadap siswa ABK masih perlu diperkuat sesuai dengan Deklarasi Dunia di Jomtien (1990) dan Dakar (2000) tentang prinsip-prinsip Pendidikan untuk Education for All.

\section{Hak Memperoleh Bantuan Fasilitas Belajar, Beasiswa, atau Bantuan Lain sesuai dengan Kelainan yang Disandang}

Komponen keempat yang berkaitan dengan hak memperoleh perlakuan adalah hak memproleh bantuan fasilitas belajar. Hasil analisis disajikan pada Tabel 3.

\section{Tabel 3: Hasil Analisis Hak Memperoleh} Bantuan Fasilitas Belajar

\begin{tabular}{lcc}
\hline \multicolumn{1}{c}{ Butir Angket } & \multicolumn{2}{c}{ Jawaban } \\
\cline { 2 - 3 } & Ya & Tidak \\
\hline Sekolah memfasilitasi & & - \\
semua kebutuhan & \\
belajar bagi siswa yang \\
mempunyai kebutuhan \\
khusus. \\
Guru berperan untuk \\
membantu siswa \\
berkebutuhan khusus \\
bersosialisasi di \\
lingkungan sekolah
\end{tabular}

Berdasarkan Tabel 3, menunjukkan bahwa hak siswa untuk memperoleh bantuan fasilitas belajar, beasiswa, atau bantuan lain yang sesuai dengan kelainan yang disandang dan persyaratan yang berlaku telah dipenuhi oleh pihak sekolah secara optimal. Dapat dilihat dari dua pernyataan angket di atas bahwa semua responden guru menjawab "ya" dalam pemenuhan kebutuhan dan fasilitas belajar siswa ABK. Hasil wawancara dengan guru juga memperkuat hasil angket, bu Lili Riskiningtyas sebagai responden wawancara mengatakan bahwa pihak sekolah selalu berupaya untuk memberikan fasilitas belajar yang menunjang kelancaran proses belajar siswa ABK. Hasil pengamatan yang dilakukan menguatkan kedua data sebelumnya, bahwa memang tersedia fasilitas bantuan untuk ABK seperti adanya mainan puzzle atau pembuatan prakarya yang dilakukan siswa dengan didampingi dan dibimbing guru, kegiatan ini dirancang untuk melatih dan mengembangkan kemampuan motorik siswa ABK. Menurut Wahyuno (2014) dalam 
melaksanakan pembelajaran di kelas inklusif, selain memodifikasi kurikulum disesuaikan dengan tingkat kemampuan $\mathrm{ABK}$, guru kelas hendaknya menggunakan berbagai jenis media/ alat peraga. Lebih lanjut juga dinyatakan bahwa dalam melaksanakan tugas pembelajaran perlu didukung ruang bimbingan khusus serta media/alat pembelajaran khusus bagi ABK.

\section{Hak untuk Memperoleh Penilaian Hasil Belajar}

Komponen kelima berkaitan dengan pemenuhan hak anak berkebutuhan khusus yang ditelaah adalah hak untuk memperoleh penilaian hasil belajar. Hasilnya disajikan pada Tabel 4.

Tabel 4. Hasil Analisis Hak untuk Memperoleh Penilaian Hasil Belajar

\begin{tabular}{lcc}
\hline \multirow{2}{*}{ Butir Angket } & \multicolumn{2}{c}{ Jawaban } \\
\cline { 2 - 3 } & Ya & Tidak \\
\hline $\begin{array}{l}\text { Guru melakukan penilaian hasil } \\
\text { belajar siswa ABK }\end{array}$ & orang & - \\
$\begin{array}{l}\text { Sekolah selalu memantau } \\
\text { tahap perkembangan belajar }\end{array}$ & 7 orang & - \\
semua siswa termasuk siswa \\
berkebutuan khusus.
\end{tabular}

Berdasarkan Tabel 4, menunjukkan bahwa guru selalu melakukan penilaian hasil belajar terhadap siswa ABK seperti siswa lainnya yang bukan ABK. Selain melakukan penilaian secara tertulis, siswa $\mathrm{ABK}$ juga mendapatkan penilaian hasil belajar berdasarkan hasil pengamatan guru terhadap seluruh kegiatannya di lingkungan sekolah. Dalam wawancaranya, bu Lili juga menyebutkan bahwa penilaian yag digunakan untuk mengukur hasil belajar siswa ABK sama dengan penilaian yang dilakukan kepada siswa bukan $A B K$. Berdasarkan hasil observasi yang dilakukan, siswa ABK diberikan buku penghubung antara orang tua dan guru damping untuk selalu memantau kegiatan yang dilakukan oleh siswa selama di sekolah. Buku penghubung tersebut dikhususkan untuk anak ABK. Buku penghubung diberikan kepada orang tua agar orang tua dapat selalu memantau seluruh aktivitas anaknya di sekolah. Setiap hari guru damping akan menulis apa saja yang dilakukan siswanya ketika di sekolah dalam buku penghubung, kemudian pada hari itu juga siswa akan membawa buku penghubung tersebut ke rumah untuk ditujukan kepada orang tuanya lalu diparaf oleh orang tua. Keterbukaan antara orang tua dan guru damping dalam mengkomunikasikan seluruh kegiatan dan perilaku yang dilakukan siswa ABK akan memudahkan guru dalam melakukan penilaian perilaku siswa dalam rapor, karena orang tua juga mengetahui bagaimana anaknya berperilaku di sekolah. Adanya TKD (Tes Kemampuan Dasar) bagi seluruh siswa termasuk siswa ABK juga dilakukan oleh SDIT Al Irsyad Al Islamiyyah 02 Purwokerto sebagai upaya untuk melakukan penilaian hasil belajar. TKD dilakukan seperti ujian tertulis, siswa mengerjakan soal dan nantinya dikoreksi oleh guru. Tes ini bertujuan untuk mengukur kemampuan dasar siswa dari kelas 1 sampai kelas 6. Tindak lanjut dari kegiatan TKD ini yaitu, jika siswa yang mempunyai skor TKD rendah maka siswa tersebut akan mendapatkan intensifikasi setelah puang sekolah. Kegiatan intensifikasi tersebut berupa latihan mengerjakan soal-soal secara berulang sampai siswa dianggap mengalami peningkatan kemampuan dari sebelumnya.

\section{Hak Menyelesaikan Program Pendidikan Lebih Awal dari Waktu yang Ditentukan}

Komponen keenam yang ditelaah adalah hak menyelesaikan program pendidikan lebih awal dari waktu yang ditetapkan. Hasil analisis data secara garis besar disajikan pada Tabel 5 .

\section{Tabel 5: Hasil Analisis Hak Menyelesaikan Program Pendidikan Lebih Awal}

\begin{tabular}{lcc}
\hline \multirow{2}{*}{ Butir Angket } & \multicolumn{2}{c}{ Jawaban } \\
\cline { 2 - 3 } & Ya & Tidak \\
\hline Sekolah memberikan keringanan & - & 7 orang \\
bagi siswa ABK untuk & & \\
menyelesaikan masa studi lebih & & \\
awal dari siswa lainnya & & \\
\hline
\end{tabular}

Berdasarkan Tabel 5. Menunjukkan bahwa hak ABK untuk menyelesaikan program pendidikan lebih awal dari waktu yang ditentukan tidak terdapat di SDIT Al Irsyad Al Islamiyyah 02 Purwokerto, hal tersebut terlihat dalam hasil angket pada tabel di atas. Pihak guru juga menjelaskannya dalam kegiatan wawancara, bahwa kegiatan belajar mengajar yang terselenggara di SDIT Al Irsyad Al Islamiyyah 02 Purwokerto tidak memberikan 
"keistimewaan" kepada siswa ABK untuk menyelsaikan program studinya dengan waktu yang lebih cepat. Semua siswa dinyatakan lulus jika memang telah memenuhi standar/kriteria yang ditetapkan oleh pihak sekolah. Siswa ABK maupun siswa bukan ABK harus memenuhi semua kriteria tersebut untuk dapat menyelesaikan masa studinya di SDIT Al Irsyad Al Islamiyyah 02 Purwokerto.

\section{Hak Memperoleh Layanan Khusus sesuai dengan Jenis Kelainan}

Komponen ketujuh yang ditelaah adalah hak memperoleh layanan khusus sesuai dfengan jenis kelainan. Hasil analisis secara garis besar disajikan pada Tabel 6.

Tabel 6: Hasil Analisis Hak Memperoleh Layanan Khusus sesuai Jenis Kelainan

\begin{tabular}{lcc}
\hline \multirow{2}{*}{ Butir Angket } & \multicolumn{2}{c}{ Jawaban } \\
\cline { 2 - 3 } & Ya & Tidak \\
\hline $\begin{array}{l}\text { Sekolah menyelenggarakan } \\
\text { program layanan khusus bagi }\end{array}$ & orang & - \\
siswa dengan kebutuhan khusus & & \\
\hline
\end{tabular}

Berdasarkan Tabel 6, dapat disimpulkan bahwa siswa ABK mempunyai hak untuk mendapatkan layanan khusus dari pihak sekolah sesuai dengan jenis kelainan yang disandang. Hak ini telah diterima secara maksimal oleh siswa ABK di SDIT Al Irsyad Al Islamiyyah 02 Purwokerto. Hasil wawancara juga menunjukkan hasil yang sama dengan hasil angket yang diperoleh, menurut pemaparan dari pihak guru, layanan khusus yang diperoleh siswa ABK yaitu dengan adanya guru damping yang akan mendampingi siswa ABK di lingkungan sekolah, baik saat proses pembelajaran di kelas maupun kegiatan di luar kelas. Berdasarkan hasil observasi, pelayanan khusus yang didapatkan oleh siswa ABK yaitu adanya jam tambahan mata pelajaran yang dilakukan setelah pulang sekolah. Hal tersebut dilakukan agar siswa ABK yang mengalami keterlambatan dalam menerima materi di kelas tidak ketinggalan materi dengan siswa normal lainnya.

Hasil penelitian menunjukkan bahwa SDIT Al Irsyad Al Islamiyyah 02 Purwokerto telah mampu menerapkan konsep sekolah inklusi dengan cukup baik. Meski masih belum semua hak ABK terpenuhi, namun secara umum hak-hak ABK telah dapat terpenuhi. Pemenuhan hak siswa ABK telah sesuai dengan jaminan konstitusi dan peraturan perundang-undangan Indonesia.

Berdasarkan hasil penelitian ini, dapat disimpulkan bahwa secara umum hak anak berkebutuhan khusus telah terpenuhi. Dari tujuh komponen yang diteliti, ada enam komponen yang menunjukkan terpenuhi, dan hanya satu komponen yang belum terpenuhi. Keenam komponen yang terpenuhi tersebut adalah: (1) hak memperoleh perlakukan sesuai bakat, minat, kemampuan, dan kelainannya, (2) hak memperoleh pendidikan agama sesuai dengan agama yang dianutnya, (3) hak me ngikuti program pendidikan, (4) hak memperoleh bantuan fasilitas belajar, beasiswa, atau bantuan lain sesuai dengan kelainan yang disandang, (5) hak untuk memperoleh penilaian hasil belajar, dan (6) hak memperoleh layanan khusus sesuai dengan jenis kelainan. Sedangkan yang masih belum terpenuhi adalah hak menyelesaikan program pendidikan lebih awal dari waktu yang ditentukan.

Hasil penelitian ini sesuai dengan hasil kajian Rahayu (2013) yang dilakukan pada pendidikan anak usia dini yang menunjukkan bahwa pendidikan perlu memberikan pelayanan terhadap anak berkebutuhan khusus. Pelayanan terhadap anak berkebutuhan khusus masih belum dilakukan secara optimal. Penyelenggaraan pendidikan inklusif merupakan langkah yang tepat untuk memberikan pelayanan yang maksimal terhadap anak berkebutuhan khusus.

Hasil penelitian ini juga sesuai dengan hasil kajian Utina (2014) yang mengemukakan prinsip pendidikan anak disability adalah prinsip kasih sayang, prinsip layanan individual, prinsip kesiapan, prinsip keperagaan, prinsip motivasi, prinsip ketrampilan, prinsip penanaman dan penyempurnaan sikap. Hasil penelitian ini juga sejalan dengan hasil kajian Hermanto (2010) yang menekankan pentingnya manajemen sekolah inklusif yang untuk menjamin pelayanan pendidikan anak berkebutuhan khusus.

Hasil penelitian ini juga sesuai dengan penelitian Indriawati (2013) yang menunjukkan bahwa dalam rangka pelaksanaan tugas diperlukan sumber daya manusia maupun sumber daya finansial di sekolah inklusi. Sejauh ini alokasi sumber daya (resources) yang dimaksud belum terpenuhi. Selain itu struktur birokrasi pada pendidikan inklusif menjadi kendala mendasar. Kondisi ini berimplikasi pada 
tidak efektifnya implementasi kebijakan. Dengan demikian, pelayanan pendidikan terhadap anak berkebutuhan khusus masih belum sepenuhnya terpenuhi.

Hasil penelitian ini juga sejalan dengan hasil penelitian Triwulandari dan Pandia (2015) yang menyatakan bahwa belum sepenuhnya guru memiliki positif terhadap anak berkebutuhan khusus. Salah satu aspek yang berkaitan dengan sikap guru tersebut adalah pengalaman mengikuti pelatihan dan peran kepala sekolah. Oleh karena itu, dapat digarisbawahi bahwa pelayanan pendidikan terhadap anak berkebutuhan khusus masih belum maksimal.

Hasil penelitian ini juga sejalan dengan kajian Rahardja (2010) yang menekankan pentingnya memberikan layanan pendidikan yang optimal untuk anak berkebutuhan khusus. Kecenderungan yang secara signifikan mempengaruhi pendidikan luar biasa dewasa ini adalah pendidikan inklusif, akuntabilitas dan aksesibilitas pembelajaran, dukungan perilaku yang positif, serta kolaborasi. Apapun bentuk layanan pendidikan dan dimanapun layanan pendidikan itu diberikan kepada anak berkebutuhan pendidikan khusus, pemerintah seyogyanya menyediakan berbagai alternatif layanan pendidikan sebagai pilihan. Dalam kaitan ini kompetensi yang dibutuhkan untuk mengelola pembelajaran di sekolah inklusi menurut (Poerwanti. 2013) diantaranya: (1) kemampuan asesment awal, yaitu kemampuan diagnosis awal, (2) metode pembelajaran inovatif dan kreatif sesuai kebutuhan, (3) kompetensi umum dan wawasan yang luas tentang ABK, (4) pemahaman tentang pendidikan khusus, (5) kemampuan mengembangkan terapi khusus, (6) pengenalan alat peraga, dan asesment hasil belajar.

Hasil penelitian ini juga sejalan dengan hasil penelitian Fuadi (2015) yang menunjukkan bahwa belum semua kategori anak berkebutuhan khusus diterima menjadi peserta didik program pendidikan inklusif. Hal tersebut berkaitan dengan belum terpenuhinya sumber daya sekolah yang memadai. Hal itu berarti di sekolah inklusi juga masih belum menunjukkan layanan pendidikan yang maksimal bagi anak berkebutuhan khusus. Oleh karena itu, berdasarkan beberapa hasil penelitian ini tersebut, dapat digarisbawahi bahwa layanan pendidikan untuk anak berkebutuhan khusus masih perlu ditingkatkan.

\section{SIMPULAN DAN SARAN}

\section{Simpulan}

Berdasarkan hail penelitian disimpulkan bahwa sekolah telah mampu menerapkan konsep sekolah inklusi dengan cukup baik. Meski masih belum semua hak ABK terpenuhi, namun secara umum hak-hak ABK telah dapat terpenuhi. Hak yang belum terpenuhi adalah pemberian kesempatan yang sama dalam keterlibatan berbagai kegiatan sekolah. Sedangkan hak-hak yang cukup terpenuhi adalah hak memperoleh perlakukan sesuai bakat, minat, kemampuan, dan kelainannya, hak memperoleh pendidikan agama sesuai dengan agama yang dianutnya, hak mengikuti program pendidikan, hak memperoleh bantuan fasilitas belajar, beasiswa, atau bantuan lain sesuai dengan kelainan yang disandang, hak untuk memperoleh penilaian hasil belajar, dan hak memperoleh layanan khusus sesuai dengan jenis kelainan. Hal ini disebabkan siswa ABK di sekolah inklusi masih dianggap sebagai beban daripada suatu tanggung jawab pendidikan.

\section{Saran}

Berdasarkan temuan penelitian, maka dapat diberikan saran untuk melakukan peningkatan layanan pendidikan kepada anak atau siswa berkebutuhan khusus. Hak-hak siswa ABK masih terus perlu disosialisasikan dan diperjuangkan agar kesadaran terhadap pemenuhan hak-hak ABK semakin terus meningkat. Mengingat masih belum sepenuhnya dapat memberikan pelayanan terhadap anak berkebutuhan khusus, maka kiranya sekolah perlu senantiasa meningkatkan pelayanan pendidikannya terhadap anak berkebutuhan khusus. Fasilitas pendidikan perlu senantiasa ditingkatkan. Demikian juga sumber daya manusia di sekolah juga perlu senantiasa ditingkatkan, sehingga dapat memberikan pelayanan yang masimal terhadap anak berkebutuhan khusus.

\section{DAFTAR RUJUKAN}

Amin, M. 1995. Orthopedagogik Anak Tunagrahita. Jakarta: Depdikbud Dikti, Proyek Pendidikan Tenaga Guru.

Fuadi, K. 2016. Analisis Kebijakan Penyelenggaraan Pendidikan Inklusif di Provinsi DKI Jakarta. Hikmah Journal of Islamic Studies, 11 (2): $1-27$. 
Hallahan, D.P., \& Kouffman, J.M. 2006. Exceptional Children: An Introduction to Special Educationi. Boston: Pearson.

Hermanto, 2010. Penyelenggaraan Pendidikan Khusus Membutuhkan Keseriusan Manajemen Sekolah. Jurnal Pendidikan Khusus, 6 (1): $65-$ 82.

Heward, W.L. 2003. Exceptional Children: An Introduction to Special Education. New Jersey : Merril, Prentice Hall.

Indriawati, P. 2013. Implementasi Kebijakan Tugas Guru Pembimbing Khusus pada Pendidikan Inklusif di SD Negeri se-Kecamatan Junrejo Batu. Jurnal Kebijakan dan Pengembangan Pendidikan, 1 (1): 49-55.

Kartono, K. 2003. Kamus Psikologi. Bandung: Pionir Jaya.

KPAI. 2014. Kekerasan Anak di Sekolah seperti Fenomena Gunung Es. (Online), (http://kpai. go.id), diakses 23 April 2015.

Mangunsong, F. 2009. Psikologi dan Pendidikan Anak Berkebutuhan Khusus. Depok: Lembaga Pengembangan Sarana Pengukuran dan Pendidikan Psikologis (LPSP3) Fakultas Psikologi Universitas Indonesia (FPUI).

Mulyono, A. 2006. Pendidikan Anak Berkesulitan Belajar. Rineka Cipta. Jakarta.

Poewanti, E. 2013. Paradigma "Educational For $A l$ " dalam Praktek Pembelajaran Iklusi di Sekolah Dasar. Jurnal Sekolah Dasar Th.22 No. 1 Mei 2013. Malang: Jurusan KSDP FIP UM.

Rahardja, D. 2016. Pendidikan Luar Biasa dalam Perspektif Dewasa Ini. Jassi Anakku 9 (1): 7688.

Rahayu, S.M. 2013. Memenuhi Hak Anak Berkebutuhan Khusus Anak Usia Dini melalui Pendidikan Inklusif. Jurnal Pendidikan Anak. 2 (Rahardja, 2016)(2): 355-363
Sadjaah, E. 2005. Pendidikan Bahasa bagi Anak Gangguan Pendengaran dalam Keluaga. Jakarta: Depdiknas Dirjen Pendidikan Tinggi Direktorat Pembinaan Pendidikan Tenaga Kependidikan dan Ketenagaan Perguruan Tinggi.

Somad, P., \& Hernawati, T. 1995. Ortopedagogik Anak Tunarungu. Jakarta: Depdikbud Dirjen Dikti.

Somantri, S. 2006. Psikologi Anak Luar Biasa, Bandung: Refika Aditama.

Sudrajat, A., T. 2014. Pemberdayaan dan Pengembangan Sumber Daya Manusia pada Sekolah Inklusi. Jurnal Ilmu Pendidikan Vol 41 No.2 Juli 2014. Malang: FIP UM.

Tribun Jogja. 4 Juli 2014. Sekolah Masih Lakukan Diskriminasi pada Siswa Berkebutuhan Khusus Tribun Jogja, hlm. 4.

Triwulandari, A., \& Panditia, W.S.S. 2015. Sikap Guru terhadap Penerapan Program Inklusif Ditinjau dari Aspek Guru. Jurnal Pendidikan dan Pemberdayaan Masyarakat, 2 (2): 122130.

Triyanto. 2015. Laporan Monev Pelaksanaan Kurikulum 2013. Jakarta: Direktorat SMP Kemdikbud.

Utina, S.S. 2014. Pendidikan Anak Berkebutuhan Khusus. Jurnal Manajemen Pendidikan Islam, 2 (1): 72-78.

Wahyuno, E. 2014. Pengembangan Kurikulum Pendidikan Inklusif Tingkat Sekolah Dasar. Jurnal Sekolah Dasar Th.23 No.1 hal 77-84. Malang: Jurusan KSDP FIP UM.

Winarsih, M. 2007. Intervensi Dini bagi Anak Tunarungu dalam Pemerolehan Bahasa. Jakarta: Departemen Pendidikan dan Kebudayaan. Direktorat Jenderal Pendidikan Tinggi. Direktorat Ketenagaan.

Yatim. 2002. Autisme Suatu Gangguan Jiwa pada Anak-Anak. Jakarta: Pustaka Populer Obor. 